\title{
Some Deficiencies in the Mediostructure of Isichazamazwi SesiNdebele
}

\author{
Dion Nkomo, African Languages Research Institute (ALRI), University of \\ Zimbabwe, Harare, Zimbabwe (deeouf@yahoo.co.uk)
}

\begin{abstract}
In this article, a descriptive and critical analysis of the mediostructure of Isichazamazwi SesiNdebele, henceforth the ISN, is given. This analysis is made within the theoretical premises of the mediostructure and its functions. The aims of the article are to shed light on the following questions: What aspects of the mediostructure are used? Why are they used? How effectively are they used to achieve text compression/condensation and text cohesion? What improvements could be made to obtain greater user-friendliness? Such an analysis, it is hoped, will, in two ways, contribute to the development of lexicography in general and Ndebele lexicography in particular. Firstly, it is hoped to make users aware of the importance of some guidance aspects of the mediostructure to improve dictionary use. Secondly, it is hoped the pointing out of some deficiencies and possible improvements in the ISN mediostructure will be useful for the compilation of future Ndebele dictionaries.
\end{abstract}

Keywords: DICTIONARY, DICTIONARY STRUCTURE, MACROSTRUCTURE, MICROSTRUCTURE, MEDIOSTRUCTURE, CROSS-REFERENCING, ACCESS STRUCTURE, USERFRIENDLINESS, FRONT MATTER, BACK MATTER

Opsomming: 'n Aantal gebreke in die mediostruktuur van Isichazamazwi SesiNdebele. In hierdie artikel word ' $n$ beskrywende en kritiese ontleding van die mediostruktuur van Isichazamazwi SesiNdebele, voortaan die ISN, gegee. Die ontleding word gedoen binne die teoretiese gegewe van die mediostruktuur en sy funksies. Die doelstellings van die artikel is om lig te werp op die volgende vrae: Watter aspekte van die mediostuktuur word gebruik? Waarom word hulle gebruik? Hoe doeltreffend word hulle gebruik om teksverdigting/-verkorting en tekssamehang te bereik? Watter verbeteringe kan gemaak word om groter gebruikersvriendelikheid te verkry? So 'n ontleding, word gehoop, sal op twee maniere bydra tot die ontwikkeling van die leksikografie in die algemeen en van die Ndebeleleksikografie in die besonder. Eerstens word gehoop dat dit gebruikers bewus sal maak van die belangrikheid van 'n aantal leidingsaspekte van die mediostruktuur om woordeboekgebruik te verbeter. Tweedens word gehoop dat die uitwys van ' $n$ aantal gebreke en moontlike verbeteringe in die ISN-mediostruktuur nuttig sal wees vir die samestelling van toekomstige Ndebelewoordeboeke.

Sleutelwoorde: WOORDEBOEK, WOORDEBOEKSTRUKTUUR, MAKROSTRUKTUUR, MIKROSTRUKTUUR, MEDIOSTRUKTUUR, KRUISVERWYSING, TOEGANGSTRUKTUUR, GEBRUIKERSVRIENDELIKHEID, VOORWERK, AGTERWERK 


\section{Introduction}

Dictionary structure is a case of convention with 'dictionary' having become associated with a certain structure peculiar to it. For instance, viewed superficially, the megastructure, i.e. "the overall framework of the component parts" of most dictionaries is similar, because they carry the 'front matter', the 'middle matter' and the 'back matter' texts (Hartmann and James 1998: 92). According to Kammerer and Wiegand (1998, referred to by Gouws 2004), a dictionary is viewed as a carrier of texts. The texts themselves convey information to the user. The information is arranged and treated systematically according to the conventional structure of a dictionary. At a macrostructural level, a certain method of arranging lexical items, be it alphabetising, niching or nesting, has to be used. Also necessary is a systematic provision and treatment of information categories of identical lexical items. These various information categories do not occur in this order and structure in their mother contexts.

A dictionary therefore is the result of taking pieces of knowledge from their larger contexts and arranging them in a conventional structure. This data distribution structure in dictionaries leads to decontextualisation of information. It is the lexicographer's role to make this information meaningful outside its context by following the conventions of dictionary structure. The metalexicographers' role is then to make practicing lexicographers aware that the dictionary structure has a certain purpose. Metalexicographers have emphasised that a dictionary is not merely a carrier of texts; it is also a carrier of information (Gouws 2004, Gouws and Prinsloo 1998, 2005), a container of knowledge (McArthur 1986) and, according to Wiegand (1988, referred to by Tarp 2000), a utility product with a genuine purpose. The texts should therefore convey useful information to the user and exhibit some form of network which helps the user obtain optimum information from the dictionary.

The lexicographer and the practice of dictionary making exist between two often opposing forces. On the one hand are the principles prerequisite for dictionary making and on the other hand is the society often unfamiliar with the principles. Playing a balancing role, the lexicographer has to convey information to this society within the confines of the dictionary type and size and the lexicographic methods and conventions in order to meet its reference needs and skills. Given such a scenario, no perfect balance is always struck in producing a dictionary of good quality meeting the user needs and skills. While the lexicographer has to serve the society through his practice, he has no license to violate the lexicographic methods and conventions at will in producing a usable dictionary for his society. The innovations should always be carried out within the principles of dictionary making, not disregarding them in a quest to achieve more user-friendliness.

In this article, the mediostructure is brought to the fore as an important convention central to lexicography as it serves both the maker and the user of the dictionary. It is viewed as an intersection of two practices of great disparity: 
dictionary making and dictionary use. As a convention, it assists the lexicographer to gather information from different sources, compress and condense it in order to save space, and distribute it in the different access positions following a clearly spelt out macro- and microstructural system. The success of the ISN is analysed in this regard, also considering the accessibility of information.

In the analysis, the following questions are addressed: What aspects of the mediostructure are used? Why are they used? How effectively are they used to achieve text compression/condensation and text cohesion? What improvements could be made to enhance user-friendliness at the mediostructural level? Such an analysis is of particular importance to Ndebele lexicography as guidance for both the lexicographer and the user. The user is guided with the help of the mediostructure which should improve dictionary consultation. Critically viewing the mediostructure gives insights which lexicographers can consider in the production of future Ndebele dictionaries, particularly an Advanced Ndebele Dictionary (AND).

\section{The Principal Functions of the Mediostructure in a Dictionary}

This section does not intend to explore the mediostructure theoretically with a view to criticising and developing it. Only an overview based on theoretical and critical insights provided by Wiegand (2004), Gouws (2004), and Gouws and Prinsloo $(1998,2005)$ is given to create a formal base for the analysis of the ISN mediostructure. To arrive at an informed analysis, a clear description of the mediostructure and its functions is needed.

According to Gouws and Prinsloo (1998: 17), the mediostructure is the system of cross-referencing used to establish relations among different components of a dictionary. In simpler terms, it is a cross-reference structure by which is meant "the network of cross-references which allows compilers and users of a reference work to locate material spread over different component parts" (Hartmann and James 1998: 32).

In the introduction, it was mentioned that a dictionary is a carrier of texts of information. By following a conventional structure in its making, a dictionary might contain related information in different texts or components of texts. Although the different dictionary texts or components of texts may contain similar or related information on language, the information would always be treated differently to avoid repetition and redundancy. A dictionary with a clear function would have a way of connecting the texts, for they are not totally independent of each other. A good quality dictionary would have, among other features, a systematic and consistent way of establishing the relationship of the dictionary texts and their dependency on one another.

When the microstructural level is considered as an example, text compression and condensation through the use of symbols and similar methods and conventions are necessary to save space. Valuable as they are to any lexicographer, the methods and conventions need to be clearly accounted for and ex- 
plained in the dictionary, usually in the front matter as guide to dictionary use. According to Gouws and Prinsloo (1998: 28), "cross-references from the front matter, especially from the user's guidelines to the central text are crucial to the user for successful or optimal retrieval of information". In this regard, they (Gouws and Prinsloo 1998: 34) add:

The front-matter texts should also include a systematic exposition of other language-specific characteristics and these have to be addressed from the central list by means of a well-developed mediostructural network.

The language-specific features should not be left unconsidered; if included, they should be explained in the front matter of the dictionary. For instance, if the front matter of a dictionary mentions orthographic problems, they should be treated consistently throughout the dictionary as explained in the front matter.

Similar principles may also be advanced with regard to the macrostructure. The popularly used alphabetical ordering presents words as if they occur as isolated units in a language, yet they are "socialized linguistic forms compiled from the speech-habits of a given speech-community" (Zgusta 1971: 17). In their socialisation, the words of a language are related as synonyms, antonyms, homonyms and so on. The dictionary structure, particularly the macrostructure, can obscure all such kinds of natural relations among the vocabulary items of a language. Wiegand (2004: 218) therefore says that "in order to uncover the connection, which is necessarily concealed by data distribution along the different access positions, a mediostructural network has to ensue". In such instances, the mediostructure would also help avoid repetition and redundancy thereby saving dictionary space. Re-establishing natural relations of linguistic and conceptual systems with a consistent use of cross-referencing devices produces a coherent and user-friendly dictionary.

However, if user-friendliness levels are to be increased, great care has to be taken in the creation of a mediostructure. This concerns the reference markers and their purported functions. Reference markers are typographic and nontypographic cross-reference devices which guide the user from a reference position to a reference address. These may be words like SEE, ALSO, GO TO, CHECK, COMPARE and many such ones in English, or symbols like an arrow pointing to another word which will be the reference address from the reference position. The communication of these needs to be explained in the front matter and their application to similar entries needs to be consistent with the explanation in the front matter. The lexicographer has to be reliable, i.e. if a user moves from one point to another as advised, the user should in fact find clear or more explicit information at that point.

Cumbersome circular referencing whereby the user is advised to find the meaning at another point, but, on arriving there, is again informed to look for the meaning at the first point, should be avoided. In fact, users resent being referred to another article to find information, when it takes more time than 
planned to consult a dictionary. It becomes worse in cases of cross-referencing where the reference address is no better than the reference position in terms of clarity and informativeness.

Moreso, reference markers may increase the density of the microstructure. Great caution is necessary in the selection of the markers so as to avoid those that may obscure other important microstructural entries, thereby compromising the user-friendliness of a dictionary.

\subsection{Isichazamazwi SesiNdebele (the ISN)}

Not all of the details on the background of the ISN and its compilation are helpful in clarifying the argument in this article. Only those affecting the mediostructure are given. For more comprehensive details on the background of the ISN, the thesis of Hadebe (2002) may be consulted. Also, a number of articles such as Hadebe (2004) and Ncube (2005) give detailed background information on the dictionary and its compilation. Nkomo (2003) analysed its microstructure, showing that the microstructure and the mediostructure interact at some point.

The ISN is the first and so far the only monolingual dictionary in Ndebele. It is a medium-sized general-purpose dictionary targeted at Ndebele speakers in general, and students at schools, colleges and universities in particular. The dictionary is corpus-aided to account for some social and regional variants, and some loan- and controversial words in Ndebele, whose speakers are a heterogeneous group. As in all Nguni languages, the ISN compilers, as shown by Maphosa $(1997,1999)$, encountered some lemmatisation problems, especially with regard to nouns and verbs.

The mediostructure of the ISN, as will emerge shortly, was partly influenced by some of the factors mentioned above. Compiling the first monolingual dictionary, the ISN editors needed to be cautious when creating the mediostructure and combining different dictionary texts to achieve userfriendliness.

\subsection{The ISN Mediostructure}

This descriptive analysis of the ISN mediostructure is undertaken at different structural levels, namely the macrostructure, the microstructure, the access structure as well as the dictionary as a unit. Given the theoretical base overviewed in the previous section, the mediostructure is expected to be a spacesaving and cohesive device which, above all, facilitates users' access to dictionary information.

At a macrostructural level, it generally seems to be every lexicographer's ambition to achieve a wide coverage of the vocabulary of the language. Some lexicographers, especially in the U.S.A., would inflate figures by counting the 
word and its derivatives, eventually boasting of the number of entries contained in their dictionaries (Béjoint 2000: 43 and Landau 2001: 29). Although the ISN editors could have wished for a more extensive dictionary, its size (its main text) was restricted to a maximum of 545 pages (Hadebe 2002). Carefully formulated headword selection and lemmatisation procedures had to be followed in the compilation process. Hadebe (2002: 91) states, for instance:

(Only) nouns denoting singular were entered except in cases where nouns denoting plural were commonly used or where only the plural forms currently exist.

Entering nouns in both their singular and plural forms throughout the dictionary would have taken up much space, but would have added little in covering the Ndebele lexicon. In cases where both the singular and plural forms were lemmatised, repetition and redundancy had to be heeded. Through the mediostructure, such entries also had to be linked to indicate their singular/plural relationship.

Synonyms and variants too form part of the macrostructure of the ISN. The following principles guided headword selection and lemmatisation with regard to synonyms and variants for the ISN (according to the Style Manual for the ISN, quoted from Hadebe 2002: 237):

(a) Any synonym should be entered as a separate headword.

(b) Any variant should be entered as a separate word.

Unlike the principle for lemmatising nouns quoted above, headword selection and lemmatisation principles regarding synonyms and variants imply repetition of similar words, or words with the same meanings. For whatever reason, repetition is not a good practice in lexicography considering the importance of dictionary space. Where it is practised, it should be justified convincingly.

Briefly focusing the discussion on some types of macrostructural entries has shown the need for cross-referencing for reasons of space economy and establishing relationships. The sets identified include singular/plural forms, synonyms and variants. By looking at the method of cross-referencing among the identified sets, microstructural categories will inevitably be discussed as well. The discussion will be directed by the following examples and others in the appendix which lists articles having some irregularities with regard to the mediostructure.

(1) iliva [iva] ... BONA ameva. (thorn ... SEE thorns.)

(2) amabhanga ... 2 BONA ibhanga. (banks ... 2 SEE bank.)

(3) isenku ... BONA ithonga. (ghost (S1) ... SEE S2.)

(4) ithonga ... BONA idlozi. (ancestor (S1) ... SEE S2.)

(5) idorobho ... BONA idolobho. (town (V1) ... SEE V2.)

(6) ijiphi [ijibhi]... BONA ijibhi. (jeep (V1) ... SEE V2.) 


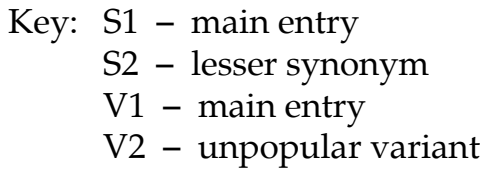

A brief glance at examples (1)-(6) and many similar ones on every page of the ISN is likely to establish the belief that cross-referencing is an effective spacesaving device in the dictionary. The ISN editorial team itself, as Hadebe (2002: 101) rightfully states, is convinced of this:

The extensive use of cross-referencing enabled the lemmatization of up to twenty thousand entries in a six hundred page dictionary. It . . . saves space and avoids repetition of definitions.

While this is true, it may be realised that with greater caution in adhering to the principle behind cross-referencing, much more entries could have been conveniently added without making the dictionary bigger. There are numerous cases of repetition. For instance, some cross-referenced synonyms like ikhehla/ixhegu (old man), abalozi/idlozi (ancestor(s)) and variants like isingakethiso/isingathekiso (metaphor) in each case carry the same definitions. When it comes to defining, one article should carry the definition while it should be indicated as part of its microstructure that it has a relationship with the other which it defines. These examples run counter to the editorial policy of employing cross-referencing to save space and avoid repetition of definitions.

There is also no need to treat a lexical item, say a variant, as an unpopular form using the popular form as definition, but giving as part of its microstructure an indication that the popular form is its variant. Many variants and synonyms in the ISN have been treated as exemplified in (7):

(7) amadilikelana [amadilikelane] bz 6. Amadilikelana ngamathumbu amancane aseduze lamalulu alobulongwe obulula.

amadilikelane [amadilikelana] bz 6. BONA amadilikelana.

If amadilikelane is a variant of amadilikelana (small intestines in animals like cattle), amadilikelane should carry a definition indicating amadilikelana as its variant, but it needs not also to be stated that the former is a variant of the latter.

Since it is given in the initial entry that amadilikelane is a variant of amadilikelana, it is also given that the reverse is true, making it redundant to indicate it in the latter article. With this treatment, the latter article would take up only one line. At least fifteen instances were identified in the first three pages of the dictionary, which, if this pattern is followed in the rest of the dictionary, would amount to a considerable number over three hundred pages. This seems to be more than an accidental mistake in the ISN mediostructural system. As such, the use of the mediostructure to save space is not exploited to the maximum, especially with regard to variants and synonyms. 
'BONA' is the reference marker for all instances of cross-referencing in the ISN. As shown in the glosses of examples (1)-(6), it means 'SEE', which directs the user to the reference target for the definitions or more explicit information. This is satisfactory since the reference mark is a very simple word whose guidance cannot confuse any user.

What is likely to reduce user-friendliness of the mediostructural system of the dictionary is the impression given that there is only one form of relation between the cross-referenced sets, which is not true. Since these relationships have different ways of representation in the dictionary, this could also have been applied to their defining. Synonyms are represented by 'FAN' which represents 'amagama alengcazelo efanayo', meaning 'synonyms' in English. Variants are placed in square parentheses immediately after the headwords. Apart from the prefixes, there is no clear way of representing singular/plural nouns, but this is not likely to trouble Ndebele speakers.

Since the relations that necessitated cross-referencing in the ISN are different and deservedly differently represented, would it not have been also prudent for the editors to use different reference markers when cross-referencing them? There is a wide range of guide words used as reference markers in English dictionaries. Ndebele cannot be seen wanting in this regard. 'KHA' for 'KHANGELA' which is a near synonym to 'BONA' could have been used for one set (singular/plural nouns or variants) so that ' BONA ' is not overburdened with different relations. Lesser synonyms could have been defined in the form of short sentences like "Ikhehla lixhegu" which would still be an implicit form of referring the user to the fully defined stronger synonym without taking up extra space. This method has partly been used in Isichazamazwi SezoMculo (ISM), the Ndebele musical terms dictionary, with the aim of achieving greater user-friendliness. If this proves to be the case, it should be considered in the compilation of the AND.

Apart from being useful to the dictionary-maker as a way of saving space, the mediostructure is an integral part of the access structure of the dictionary. By access structure is meant, according to Hartmann and James (1998: 2), "the component parts of the overall design of a reference work which allow the user to search for a particular item of information". Therefore, dictionary-makers should not concern themselves so much about the number of entries they can accommodate in a dictionary if they employ a certain method of text compression and/or cross-referencing which leaves their target users in the lurch. Wiegand (2004: 218) emphasises that "a mediostructural selection should result which depends decisively on the primary dictionary functions and consequently on the intended user relation".

With reference to Wiegand and other metalexicographers who champion the user-perspective in dictionary making, it has been reiterated that a dictionary is a utility product. For instance, Béjoint (2000: 133) stresses that "the dictionary is an object that is used, almost an artifact". For any dictionary to be useful, its information has to be accessible at all its structural levels. 
The ISN editors' use of a simple word as a reference marker is to be commended, although the limitation of its application has been shown. The crossreferencing does not overburden the microstructure with alien markers and other unnecessary conventions, which may make the user's inner search path difficult.

However, the main reason for the employment of cross-references is, as Svensén (1993: 199) notes, that "some parts of meaning units may be treated at different places while users may assume that the information has been exhausted within one entry". So, when the user finds a reference from one article to another, at that article, there should be given more information, which would solve the user's problem. In the case of the ISN, for instance, when the user is referred from iliva (thorn) to ameva (thorns) for its meaning, a definition giving the meaning of iliva certainly has to be provided. There are numerous cases in the ISN which do not meet this requirement. A few will be discussed to illustrate some of the problems the user is likely to encounter.

Following the mediostructure, the user may discover that in some cases there is no difference between cross-referenced entries in terms of information provision and treatment. For instance, both idolobho and idorobho (town) or amachaphachapha and amabalabala (spots) lack definitions, in both cases, the one being referred to the other. This circular referencing leaves the user stranded. In other cases, like isambuzi being referred to ithoyilethi (toilet), the entry to which the user is referred is not even lemmatised, thus creating an equally futile search-path.

There are some other cases of cross-referencing in the ISN eventually causing the user's search-path to be winding, if not misleading. One illustrative example is cross-referencing in the article isenku (ghost), which is defined using its synonym ithonga (ghost). Yet, there are two articles of ithonga, the other referring to 'ancestor'. This means that the user has to look at both articles. The first article does not even carry the definition; it is defined using idlozi (ancestor). For more examples, the search-path of headwords in the appendix may be followed.

So far the analysis of the ISN mediostructure has focused on the central list. It has already been emphasised that the mediostructure should eventually serve, after having made the information accessible to the user, as a cohesive device binding the dictionary texts together. The ISN as a carrier of texts contains three texts, namely the front matter, the central text and the back matter. The front matter of the ISN, 47 pages in length, is informative on the Ndebele language and the dictionary itself, giving a historical outline of the language and its speakers, a grammatical outline, an insight into the methods used at various stages of the compilation of the dictionary, the metalanguage list and the guide to the use of the dictionary. The ISN front matter, being the largest in Nguni dictionaries, was deliberately made extensive considering the fact that Ndebele has had no grammar book or monolingual dictionary prior to the ISN, which necessitated a comprehensive but concise outline of the structure of the 
language (Hadebe 2002: 106-107). In this regard, the front matter is a welladvised addition by the editors.

By enumerating in the front matter what information the dictionary contains, how it is presented and how the user can best access it, the editors managed to produce a self-contained and perhaps a useful and user-friendly reference work. The macro-, micro-, medio- and access structures are all explained and illustrated to ensure that the user is guided in all the search-paths. It is unfortunate that dictionary users often do not read this very informative text. Hopefully this habit of ignoring the front matter text would diminish as Ndebele speakers acquire more reference skills with the development of a dictionary culture.

However, as an innovation some texts like the guide to dictionary use, the outline of headword selection, defining formats and others that directly relate to and impact on dictionary use could have been strategically inserted in the main text to form what is called 'middle matter' (Hartmann and James 1998: 94) so that the user is persuaded to read them whilst searching for words. For instance, texts like Ukwethulwa Kwamagama (Presentation of Entries) or Ukwethulwa Kwengcazelo (Presentation of Definitions) could be inserted at the beginning of letters or even on the page marked Aa-Zz where the real dictionary begins. At such points, users would be more likely to read these informative texts, which are in danger of remaining unutilised in the front matter.

With regard to the front matter, still more effort could have been made at the mediostructural level to utilise the information it provides. For instance, while it is a good idea to give information on Ndebele grammar first in the front matter through the grammatical outline and the metalanguage list and then in the main text as defined entries, the texts containing the information are not linked. Since space economy in the main texts renders definitions brief, it could have been possible to refer the user at the end of the definitions of grammatical terms to the grammatical outline for more detail. This in a way would make the user aware of the useful information contained in the front matter. Accessibility to this information would be improved, with the prospect even of improving both reference skills and dictionary culture.

The application of some crucial principles in the dictionary is not consistent with the information in the front matter, giving details about what the dictionary contains and how it may be accessed. Some irregularities have already been indicated in certain aspects of cross-referencing which might impede the user's consultation of the dictionary. There also seem to be other irregularities indicating a lack of unity between the different texts of the dictionary. One example is the inconsistent adherence to the Ndebele alphabet presented on page xxxi when spelling some country names in the back matter, for instance the Ndebele equivalents for Liberia, the Ivory Coast, Kenya, Nigeria and notably Swaziland. Even some loan-words in the main text exhibit sound clusters which are not part of the list given on page xxxii. Not everything presented in the introduction and guide to the ISN is followed consistently, which might seriously effect the unity of the dictionary. 


\section{Conclusion}

This article has explored the mediostructural aspects in the ISN, with particular focus on its weaker and impeding points, against the background of the principal functions served by the mediostructure in a dictionary as previously explained and demonstrated by Wiegand (2004), Gouws (2004), and Gouws and Prinsloo $(1998,2005)$ among others. Suggestions have been made how more positive results could have been achieved. It is hoped that for any form of revision of the ISN, the compilation of the AND and other future dictionaries in Ndebele, these suggestions would be considered. Lemmatisation of multi-lexical units like idiomatic expressions in the AND and other multi-lexical units in LSP dictionaries is likely to present more challenges at the mediostructural level.

Finally, it needs to be emphasised that focusing in the article on the deficiencies in the mediostructure of the ISN does not mean that the dictionary is without merit. Actually, its vast contribution to the development of the Ndebele language and lexicography cannot be adequately quantified. Critical reviews such as this are part of this development. Research on and studies of the language and its use will certainly educate and uplift its speakers as the dictionary gives an endangered language extra strength to survive and develop.

\section{References}

Béjoint, H. 2000. Modern Lexicography. Oxford: Oxford University Press.

Gouws, R.H. 2004. Outer Texts in Bilingual Dictionaries. Lexikos 14: 67-88.

Gouws, R.H. and D.J. Prinsloo. 1998. Cross-Referencing as a Lexicographic Device. Lexikos 8: 1736.

Gouws, R.H. and D.J. Prinsloo. 2005. Principles and Practice in South African Lexicography. Stellenbosch: SUN PReSS.

Hadebe, S. 2002. The Standardisation of the Ndebele Language through Dictionary-Making. D.Phil. Thesis. Harare/Oslo: University of Zimbabwe/University of Oslo.

Hadebe, S. 2004. Improving Dictionary Skills in Ndebele. Lexikos 14: 89-104.

Hadebe, S. (Ed.). 2001. Isichazamazwi SesiNdebele. Harare: College Press.

Hartmann, R.K.K. and G. James. 1998. Dictionary of Lexicography. London: Routledge.

Kammerer, M. and H.E. Wiegand. 1998. Über die textuelle Rahmenstruktur von Printwörterbüchern. Präzisierungen und weiterführende Überlegungen. Lexicographica 14: 224-238.

Landau, S.I. 2001. Dictionaries: The Art and Craft of Lexicography. Second Edition. Cambridge: Cambridge University Press.

Maphosa, M. 1997. The Morphological Structure of the Noun and its Implications on the Ordering of Entries in Ndebele Dictionaries. Unpublished B.A. Honours Dissertation. Harare: University of Zimbabwe.

Maphosa, M. 1999. The Morphological Structure of the Verb in Ndebele and its Implications on Headword and Sense Selection. Unpublished M.A. Dissertation. Harare: University of Zimbabwe.

McArthur, T. 1986. Worlds of Reference. Cambridge: Cambridge University Press. 
Ncube, C. 2005. Language Development or Language Corruption? The Case of Loan-words in Isichazamazwi SesiNdebele. Lexikos 15: 384-395.

Nkomo, D. 2003. The Microstructure and the Accessibility of Dictionary Information: An Analysis of Isichazamazwi SesiNdebele. Unpublished B.A. Honours Dissertation. Harare: University of Zimbabwe.

Nkomo, D. and N. Moyo (Eds.). 2006. Isichazamazwi SezoMculo. Gweru: Mambo Press.

Svensén, B. 1993. Practical Lexicography: Principles and Methods of Dictionary-Making. Oxford: Oxford University Press.

Tarp, S. 2000. Theoretical Challenges to Practical Specialised Lexicography. Lexikos 10: 189-208.

Wiegand, H.E. 1988. Was eigentlich ist Fachlexicographie? Mit Hinweisen zum Verhältnis von sprachlichem und enzyklopädischem Wissen. Munske, H.H. et al. (Eds.). Deutscher Wortschatz. Lexikologischen Studien. Ludwig Erich Schmitt zum 80. Geburtstag von seinen Marburger Schülern: 729-790. Berlin/New York: Walter de Gruyter.

Wiegand, H.E. 2004. Reflections on the Mediostructure in Special-Field Dictionaries. Also According to the Example of the Dictionary for Lexicography and Dictionary Research. Lexikos 14: 195221.

Zgusta, L. 1971. Manual of Lexicography. The Hague: Mouton and Company. 


\section{Appendix}

This is a list of some of the ISN headwords which have been found to be poorly cross-referenced. This means is that cross-referencing has not been exploited to the maximum to save space, because of repetition of synonyms or variants and definitions in a way not improving accessibility to information. In some cases, cross-referencing is ineffective in guiding the user, because of the absence of the reference address or the definition at the reference address, or because of further cross-referencing making the search-path longer. In other cases, crossreferencing is not clear enough to establish the intended relations between the reference position and reference address. It should be noted that the list only contains cases of poor cross-referencing up to page 12 of the dictionary.

ababusi
abadala
abalozi
abatshakazi
akunani
alubana
amabethe
amachaphachapha
amachaphazi
amacilikwane
amacokamo
amacubane
amadabhuli
amadakadaka
amadilikelane
amadunuselane
amafa
amafelamlonyeni
amafinyela
amafunyafunya
amagaka

ababusi

abadala

abalozi

akunani

amachaphachapha

amachaphazi

amacilikwane

amadabhuli

amadakadaka

amadilikelane

amafa

amafelamlonyen

amafunyafunya

amagaka

amagcikwane

amagciyane

amahabula

amahalawubho

amahele

amahemuhemu

amahlafuhlafu

amahlakomuzi

amahlala

amahlebezi

amahlungelo

amajinkojinko

amakaka

amakhafitha

amakhekheba

amakhosi

amakhwakhwa

amakhwengukhwengu

amalabi

amalombolombo

amalungiselo amalwa ecatsha

amamkhwezikhwezi

amanangananga

amancoko

amandambi

amandiki

amangebeza

amangqanga

amangqolo

amanhlakomuzi

amanikiniki

amanqe

amanqonjwana

amantanga

amantelo

amanxa

amanxe

amapheluphelu

amaphico

amaphivane 